\title{
A Case Study of Chrysanthemum inscriptions and poems on the Tragic Deepening of the 'The Story of the Stone' with the Talented Beauty Novel in the Early Qing Dynasty
}

\author{
Ma Shuangbo \\ The Open University of Hong Kong, China, Hong Kong, 999077
}

Keywords: Dream of Red Mansions; poetic language; chrysanthemum inscription

\begin{abstract}
Similar to novels of the early Qing Dynasty, the poems in Dream of Red Mansions share many similarities with other works of the same period, but with many innovations and developments. This paper analyzes tragic depression of novels of gifted sages and gentlemen in the early Qing dynasty influenced by the Dream of Red Mansions based on the example of chrysanthemum inscription. This paper first analyzes the poetic language in Dream of Red Mansions to realize the innovation in the application process. Then the textual relationship between the novels of gifted scholars in early Qing Dynasty and the poems in Dream of Red Mansions is studied. Finally, the emphasis is placed on the tragic deepening of Dream of Red Mansions.
\end{abstract}

\section{Innovations and Developments of the Poetic Language in Dream of Red Mansions}

In terms of the novels of gifted scholars in the early Qing Dynasty, Yujiaoli is the most representative work. In the narrative content, despite the existence of a large number of heroes' poems similar with Dream of Red Mansions, they fail to undertake the subject of the story and deepen the tragic development tendency of the fate of the characters. From the content, it covers more of their own poetic and emotional expression, but cannot be seen as a sign of the characters' fate. However, the greatest difference between the Dream of Red Mansions and the novels of gifted scholars in the early Qing dynasty was the further tragedy of the preliminary judgment by the use of lantern riddles, chrysanthemum inscriptions and other multi-layered prophecies. In the creation of Dream in Red Mansions, it attempts to evade the familiar routines in Yujiaoli and hopes to find another way to change. Through the chrysanthemum inscriptions, the general story of the novel finds a new way to express and reverses the traits of the plot development in the novels of the gifted scholars in the early Qing dynasty. However, in terms of the specific content of the creative thinking it is still lingering with the former, with the coincidental, clues similarities. The most obvious feature is the Dream of Red Mansions, in terms of the emotional settings, that follows the same route of that of Yujiaoli and Qingmengchai, which have both the hero and heroine in the novel. However, Chrysanthemum inscription also brings out the biased mindset and the potential tragic ending from the side that Baoyu hopes to be compatible with Jinyu Liangyuan and Mushi Qianmeng.

\section{Poetry and Text Correlation between Novels of gifted scholars in the early Qing dynasty and Dream of Red Mansions}

There are inextricably links between the novels of gifted scholars in the early Qing Dynasty and Dream of Red Mansions. First of all, the characteristics of poems in the novels of gifted scholars in the early Qing Dynasty are analyzed. The most common feature lies in that they all have many kinds of poems one after another. Relatively speaking, the story's interest has been improved with many poems. The poems of the main characters in Dream of Red Mansions cannot be regarded as independent poems like Pingshan Lengyan and Yujiaoli. In Pingshan Lengyan, the tragic elements were solved immediately. From this point of view, thethought depth is not that high. Dream in Red Mansions presupposes the fate of the characters, and then it can be said that there are similarities and differences between the poems of the protagonists and the whole story to deal with the 
conception of the former. Second, we can find the fusion of the process and the specific chapters of the poem in Dream of Red Mansions. The poems of the main characters in Dream of Red Mansions cannot be regarded as independent poems like Pingshan Lengyan and Yujiaoli, which are written just for the main characters. On the fifth chapter, what Baoyu saw set out the future development of every characters. With the riddles and the establishment of Begonia Poetry Society, the second prophecy is set. In the novel, Baochai and Xiangyun's discussions on the poem of chrysanthemum played a major role in promoting the text tendency toward tragedy. Before the Chrysanthemum poems are the creation of White Crabapple poems. When Xiangyun later joined the talk of poems, the poetic atmosphere was mobilized. This makes the discussion of chrysanthemum arouses people's reading interest. Through the words of Baochai, the change of chrysanthemum in the autumn is described, which made the reason of the creation of the chrysanthemum poems appear in front of the reader and it made people know the development route of the twelve chrysanthemum poems better. The chapter narration is meaningful and thought-provoking in terms of the creation of the chrysanthemum poem, it is valuable to play up and deepen the evolution of the protagonist's fate.

\section{The Influence of the Ode to Chrysanthemum To The Deepen Of The Novel'S Tragic}

The influence of the ode to chrysanthemum to the novel's tragic and be analyzed through the poem. First of all, the autumn scenery is the comprehensive interpretation of the novel's overall tragic. The twelve chrysanthemum poems in chapter 38 of the novel are written by Tanchun for the Poetry club's activities. However, the prosperous and gorgeous images of yellow flower, frost and the setting sun highlight the chilly and lonely environment. The twelve poems start with the memory of the past prosperity and magnificence, and then mention that how time flies so we should cherish it. The authors still think that there is chance for the rejuvenation while the truth is just the opposite. The withered chrysanthemum symbolizes the loss and powerlessness, the gist of the poems is not the depiction of the beautiful picture but the forewarning of the five protagonists' fate and the crisis of the Jia family. Second, the ode to chrysanthemum is the extension of the tragic love story among Baoyu, Baochai and Daiyu. Almost all the readers of the novel will be attracted by the complicated and confusing love triangle, the chrysanthemum poems written by the three correlate with the love story mentioned in chapter 5 , and exaggerate the messing relationship among them while weaken the tragic fate of the character. Actually, the key point to affect the result of the love story is Baoyu. However, the author thinks that Baoyu loves both of the girls so he does not really want to break up with any of them. Baoyu expressed his attitude to previous Wood-stone oath of alliance in his poem Cultivation of Chrysanthemum. He was put into conflict which needs highlighting due to the thought of having cake and eating it. Poems about chrysanthemum reflect and deepen the tragedy of characters' ideal and destiny. Twelve poems about chrysanthemum fully reveal the personality of the characters using the contrast between the poetic lines and the depictions of autumn scenery reflect the tragedy of the whole story with veiled expression in titles. Their own verses lay stages for the tragedy of their ideal and destiny. The tragedy of Xiangyun's ideal is that she has realized her haughty feelings can't get accepted in Jia Mansion, just like Tanchun. It could be found that Tanchun, Baochai, Xiangyun and Daiyu's tragedies are deepened from the original poems to the creation of chrysanthemum poems in the $38^{\text {th }}$ chapter according to the comprehensive analysis of their chrysanthemum poems.

Poetics plays an extremely important supporting role in the appreciation of chrysanthemum poems and the relations between poetics are sufficient evidence embodying the tendency of characters' fate. Twelve chrysanthemum poems combine numerous buried plots and predictions of the poems to further deepen the tragedy of characters' ideal and fate, based on the poem creation of Baochai, Baoyu, Xiangyun, Daiyu and Tanchun along with public comments of Li Wan and their comments on each other. Chrysanthemum poems and poetics form the real contrast which greatly improves the poetic tragedy at spiritual level to easily strike a responsive chord in readers' hearts. 


\section{Conclusions}

Twelve Chrysanthemum poems, through the way of the three autumn pave, warn to deepen the verdict Bao, Dai, Chai three emotional tragedies. At the same time, the poetic theory of Tan Chun and Bao Chai, Dai Yu and Xiang Yun not only complement each other, but also precisely show the tragedy of their characters. However, it is not advisable to excessively elevate the tragic value of Chrysanthemum inscriptions on the tragic value of "Dream of Red Mansions" while ignoring the ideological significance of poetry in the novels about gifted scholars and gifted persons in the early Qing Dynasty. 'Dream of Red Mansions' in the emotional conception of the characters generally the continuation of the former 'Yu Jiao Li', 'Qing Su Tuo' in the early Qing genius and beauty novels, 'one genius one beauty' set. Therefore, we should not completely criticize the connection between them in the subject creation because the 'Dream of Red Mansions' begins with a critical opinion on the novels of genius and beauty. Similarly, we should not deliberately belittle the novels like 'Yu Jiao Li' and 'Ping Shan Leng Yan' in the early Qing Dynasty in order to highlight the tragic special of 'Dream of Red Mansions'. It is the most suitable and appropriate way of reading comprehension that the chrysanthemum inscribed title is a dialectical and synthetical part in the tragedy deepening of Dream of Red Mansions novels and the creative part of interlinking between the two in the 'Dream of Red Mansions' and the novels of gifted scholars and gifted persons in the early Qing dynasty. In this way, not only can we master the strengths and weaknesses of the novels about gifted scholars and gifted persons in the early Qing dynasty of the textual creation of 'Dream of Red Mansions', but also understand the deepening the role of the title of the poem relatively objectively by the connection between the poem and the text.

\section{References}

[1] Xu Longfei, Literary Genres of Gifted Scholars and Beauty in Late Ming and Early Qing Dynasty, Beijing: Culture and Arts Publishing, 2010.

[2] Lv Peng revision, [Qing Dynasty] Zhi Yanzhai comment, [Qing Dynasty] Cao Xueqin, Zhi Yanzhai Recomment Shi Tou Ji in the year 1975, Shaanxi: Writers Publishing, 2010. 